\title{
Multiple Channel Interactions Explain the Protection of Sympathetic Neurons from Apoptosis Induced by Nerve Growth Factor Deprivation
}

\author{
Shuli Xia, ${ }^{1,3}$ Patricia A. Lampe, ${ }^{2}$ Mohanish Deshmukh, ${ }^{2}$ Aizhen Yang, ${ }^{1,3}$ Barry S. Brown, ${ }^{4}$ \\ Steve M. Rothman, ${ }^{1,2}$ Eugene M. Johnson Jr, ${ }^{1,2,3}$, and Shan Ping $\mathbf{Y u}^{1,3}$ \\ Departments of ${ }^{1}$ Neurology and ${ }^{2}$ Molecular Biology and Pharmacology and ${ }^{3}$ Center for the Study of Nervous System \\ Injury, Washington University School of Medicine, St. Louis, Missouri 63110, and ${ }^{4}$ DuPont Pharmaceuticals Research \\ Laboratories, General Pharmacology, Wilmington, Delaware 19880
}

We investigated the neuroprotective properties of two M-type $\mathrm{K}^{+}$channel blockers, linopirdine and its analog XE991, in rat sympathetic neurons deprived of nerve growth factor (NGF). Linopirdine and XE991 promoted sympathetic neuronal survival 48-72 hr after NGF withdrawal in a concentration-dependent manner. Both drugs prevented neuronal apoptosis by blocking the pathway leading to the release of cytochrome $c$ and development of "competence-to-die" after NGF deprivation. Fura-2 $\mathrm{Ca}^{2+}$ imaging showed no significant difference in intracellular free $\mathrm{Ca}^{2+}\left(\left[\mathrm{Ca}^{2+}\right]_{\mathrm{i}}\right)$ in the presence or absence of NGF; linopirdine and XE991, on the other hand, caused membrane depolarization and increases in $\left[\mathrm{Ca}^{2+}\right]_{\mathrm{i}}$. Whole-cell recordings showed that linopirdine and XE991 selectively blocked the M current at neuroprotective concentrations, although they additionally inhibited other $\mathrm{K}^{+}$currents at high concentrations.
Membrane depolarization and $\left[\mathrm{Ca}^{2+}\right]_{i}$ increases induced by linopirdine and XE991 were blocked by the $\mathrm{Na}^{+}$channel blocker tetrodotoxin (TTX) or by the L-type $\mathrm{Ca}^{2+}$ channel antagonist nifedipine. TTX and nifedipine also prevented the neuroprotection elicited by linopirdine or XE991.

We propose that $\mathrm{Na}^{+}$channel activation amplifies the membrane depolarization produced by $\mathrm{M}$ channel blockade and is essential for subsequent $\mathrm{Ca}^{2+}$ entry via the L-type $\mathrm{Ca}^{2+}$ channel. The interaction of these three classes of ion channels highlights an integrated anti-apoptosis mechanism in sympathetic neurons.

Key words: apoptosis; calcium; M-type potassium channel; nerve growth factor; sympathetic neuron; cortical neuron; tetrodotoxin; linopirdine; XE991
Apoptosis is an important regulatory process during the development of the nervous system. It also contributes to neuronal loss in stroke, trauma, and some neurodegenerative disorders (Oppenheim, 1991; Choi, 1996; Henderson, 1996). Elevation of extracellular $\mathrm{K}^{+}\left(\left[\mathrm{K}^{+}\right]_{\mathrm{o}}\right)$ blocks apoptosis in neurons from a variety of peripheral and central locations, including sympathetic ganglia, hippocampus, neocortex, cerebellum, and dorsal root ganglia (Gallo et al., 1987; Collins and Lile, 1989; Koike et al., 1989; Collins et al., 1991; Franklin et al., 1995; Galli et al., 1995; Pike et al., 1996; Tong et al., 1997; Yu et al., 1997; Colom et al., 1998). Two different mechanisms have been proposed to explain the anti-apoptotic effect of high $\left[\mathrm{K}^{+}\right]_{\mathrm{o}}$. In sympathetic neurons, cerebellar granule cells, and some other types of neurons, the antiapoptotic effect of elevated $\left[\mathrm{K}^{+}\right]_{\mathrm{o}}$ has been shown to be mediated by increased intracellular $\mathrm{Ca}^{2+}$ concentration $\left(\left[\mathrm{Ca}^{2+}\right]_{\mathrm{i}}\right)$ as a result of membrane depolarization and activation of the L-type voltage-dependent $\mathrm{Ca}^{2+}$ channels (Gallo et al., 1987; Collins and Lile, 1989; Koike et al., 1989; Franklin et al., 1995; Galli et al., 1995; Tong et al., 1997). In contrast, recent work on central

Received April 25, 2001; revised Oct. 17, 2001; accepted Oct. 22, 2001.

This work was supported by National Science Foundation Grant IBN-9817151 (S.P.Y.), American Heart Association Grant 0170064N (S.P.Y.), and National Institutes of Health Grants NS37773 (S.M.R.) and NS38651 (E.M.J.).

Correspondence should be addressed to Shan Ping Yu, Department of Neurology and Center for the Study of Nervous System Injury, Box 8111, Washington School of Medicine, St. Louis, MO 63110. E-mail: yus@neuro.wustl.edu.

M. Deshmukh's present address: Neuroscience Center, University of North Carolina, Chapel Hill, NC 27599.

Copyright (C) 2001 Society for Neuroscience $\quad 0270-6474 / 01 / 220114-09 \$ 15.00 / 0$ neurons, such as neocortical neurons, and several peripheral cells supports the idea that elevated extracellular $\mathrm{K}^{+}$, or $\mathrm{K}^{+}$channel blockers, such as tetraethylammonium (TEA), suppress apoptosis attributable to prevention of $\mathrm{K}^{+}$efflux and intracellular $\mathrm{K}^{+}$loss (Yu et al., 1997, 1998, 1999; Colom et al., 1998; Dallaporta et al., 1998; Hughes and Cidlowski, 1999). This protective effect can be independent of changes in $\left[\mathrm{Ca}^{2+}\right]_{\mathrm{i}}$ (Yu et al., 1997, 1998, 1999).

Given these results, we wondered whether newly developed, selective $\mathrm{M}$-type $\mathrm{K}^{+}$channel blockers would be anti-apoptotic in cultured rat sympathetic neurons after nerve growth factor (NGF) deprivation, and, if so, whether the neuroprotective mechanism would be mediated by elevation of $\left[\mathrm{Ca}^{2+}\right]_{i}$ or direct inhibition of $\mathrm{K}^{+}$efflux. Sympathetic neurons undergo apoptosis within 48-72 hr after NGF withdrawal (Edwards et al., 1991; Deckwerth and Johnson, 1993; Deshmukh and Johnson, 1997; Werth et al., 2000). It has been shown that NGF deprivation induces two parallel processes that are sufficient to induce apoptotic death: (1) protein synthesis-dependent, caspase-independent loss of mitochondrial cytochrome c; and (2) the development of "competence-to-die," which requires no macromolecular synthesis (Deshmukh and Johnson, 1998). This cell death can be inhibited by cycloheximide (CHX), boc-aspartyl(OMe)-fluoromethylketone (BAF), and some other neuroprotective agents (Martin et al., 1988; Rydel and Greene, 1988; Koike et al., 1989; Franklin et al., 1995; Deshmukh et al., 1996; McCarthy et al., 1997).

Linopirdine [3,3-bis(4-pyridinylmethyl)-1-phenylindolin-2-one; DUP996] and its analog XE991 [10,10-bis(4-pyridinylmethyl)$9(10 \mathrm{H})$-anthracenone] are potent blockers of M-type $\mathrm{K}^{+}$chan- 
nels in a variety of neurons (Costa and Brown, 1997; Schnee and Brown, 1998; Wang et al., 1998, 2000; Brown and Yu, 2000). They are also representative of a class of cognition-enhancing compounds that increase the release of neurotransmitters (Kristufek et al., 1999). The neuroprotective potential of these compounds, however, has not been investigated previously. The present study demonstrates that $\mathrm{M}$ channel blockers are highly neuroprotective against NGF deprivation-induced apoptosis in sympathetic neurons; the protection requires block of the $\mathrm{M}$ channel, as well as activation of voltage-gated $\mathrm{Ca}^{2+}$ and $\mathrm{Na}^{+}$channels.

\section{MATERIALS AND METHODS}

Sympathetic neuronal cultures. Primary cultures of sympathetic neurons from superior cervical ganglion were prepared by dissecting tissue from rat fetuses on embryonic day 21 as described previously (Johnson and Argiro, 1983; Martin et al., 1988). Briefly, the ganglia were placed in Leibovitz's L-15 medium with L-glutamine (Life Technologies, Gaithersburg, MD), digested with $1 \mathrm{mg} / \mathrm{ml}$ collagenase (Worthington, Freehold, NJ) for $30 \mathrm{~min}$ at $37^{\circ} \mathrm{C}$, followed by another $30 \mathrm{~min}$ digestion in trypsin (Worthington), and then resuspended in modified HBSS. The digestion was stopped by AM50, which contained minimum essential medium with Earle's salts (no L-glutamine), $10 \%$ fetal calf serum (HyClone, Logan, UT), $2 \mathrm{~mm}$ glutamine, $20 \mathrm{~mm}$ floxuridine, $20 \mathrm{~mm}$ uridine, $100 \mathrm{U} / \mathrm{ml}$ penicillin, $100 \mu \mathrm{g} / \mathrm{ml}$ streptomycin, and $50 \mathrm{ng} / \mathrm{ml}$ mouse $2.5 \mathrm{~S}$ NGF (Harlan Sprague Dawley, Indianapolis, IN). Ganglia were then dissociated into a suspension of individual cells and preplated on a 100 $\mathrm{mm}$ Falcon or Primaria culture dish (Becton Dickinson, Lincoln Park, $\mathrm{NJ})$. After $2 \mathrm{hr}$, the medium containing the unattached cells, virtually all neurons, was removed and triturated again.

The cell suspension was plated on 24-well tissue culture plates (Costar, Wilmington, MA), glass-bottomed $35 \mathrm{~mm}$ dishes (Corning, Corning, NY), or two-well chamber slides (Nunc, Naperville, IL) that have been coated previously with collagen and air dried. Cells were allowed to attach for $0.5-2 \mathrm{hr}$. Approximately 1500 cells, or $25 \%$ of the cells obtained from a single ganglion, were plated into each well. Cultures were then incubated at $37^{\circ} \mathrm{C}$ in $5 \% \mathrm{CO}_{2}$ and $95 \%$ air atmosphere.

Neocortical cultures. Mixed cortical cultures (containing neurons and a confluent glia bed) were prepared as described previously (Rose et al., 1993). Dissociated neocortices obtained from fetal mice were plated onto a previously established glial monolayer at a density of $0.35-0.40$ hemispheres per milliliter on 24-well plates (Falcon or Primaria), in Eagle's minimal essential medium (Earle's salts) supplemented with $20 \mathrm{~mm}$ glucose, $5 \%$ fetal bovine serum, and 5\% horse serum. Medium was changed after 1 week to MEM containing $20 \mathrm{~mm}$ glucose and $10 \%$ horse serum, as well as cytosine arabinoside $(10 \mu \mathrm{M})$ to inhibit cell division. Experiments were performed after 10-12 d in culture.

Neuronal death-survival assay. Sympathetic neurons were plated on 24-well plates as stated above or, alternatively, on two-well chamber slides. The cultured sympathetic neurons could be killed by adding medium (AM0) lacking NGF and containing $0.05 \%$ goat anti-NGF. AM0 caused the death of the neurons over a period of 48-72 hr. For experiments with potassium channel blockers, drugs were added at the time when NGF was removed. To quantify neuronal death and survival, the cultures were fixed in $4 \%$ paraformaldehyde or $10 \%$ formalin in PBS, stained with toluidine blue, and counted using a phase-contrast microscope. Neurons were scored as viable if they had a clear nucleolus and nuclei and were clearly stained with toluidine.

Cortical neuronal cell death induced by staurosporine $(0.1 \mu \mathrm{M}, 24 \mathrm{hr})$ was assessed in 24-well plates by measuring lactate dehydrogenase (LDH) released into the bathing medium (MEM plus $20 \mathrm{~mm}$ glucose and $30 \mathrm{~mm} \mathrm{NaHCO}_{3}$ ) using a multiple plate reader (Molecular Devices, Sunnyvale, CA). Neuronal loss is expressed as a percentage of LDH release measured in each experimental condition normalized to negative (sham wash) and positive (complete neuronal death induced by $24 \mathrm{hr}$ exposure to $300 \mu \mathrm{M}$ NMDA) controls.

Immunohistochemistry. Sympathetic neuronal cultures were immunostained as described previously (Easton et al., 1997; Deshmukh and Johnson, 1998). Briefly, cells were grown on collagen-coated, two-well glass chamber slides. For staining, cultures were washed once with PBS and fixed with $4 \%$ paraformaldehyde in PBS for $30 \mathrm{~min}$ at $4{ }^{\circ} \mathrm{C}$, followed by washing three times with Tris-buffered saline (TBS) $(0.9 \% \mathrm{NaCl}$ and $100 \mathrm{~mm}$ Tris-HCl, $\mathrm{pH}$ 7.6). After incubation in blocking buffer (5\% goat serum and $0.3 \%$ Triton $\mathrm{X}-100$ in TBS) for $30 \mathrm{~min}$ at room temperature $\left(21 \pm 1^{\circ} \mathrm{C}\right)$, cultures were exposed to the anti-cytochrome c primary antibody (PharMingen, San Diego, CA) overnight at $4^{\circ} \mathrm{C}$. The primary antibody was diluted 1:1000 (final concentration of $0.5 \mu \mathrm{g} / \mathrm{ml}$ ) in blocking buffer. Cells were then washed three times with TBS and incubated with an anti-mouse FITC-conjugated secondary antibody (1:300 with a final concentration of $2 \mu \mathrm{g} / \mathrm{ml}$ ) (Jackson ImmunoResearch, West Grove, PA) for $2-4 \mathrm{hr}$ at $4^{\circ} \mathrm{C}$. Finally, the cells were washed twice in TBS and stained with the nuclear dye bisbenzimide (Hoechst 33258 used at $1 \mu \mathrm{g} / \mathrm{ml}$; Molecular Probes, Eugene, OR) for $15 \mathrm{~min}$ at room temperature. After washing twice with TBS, samples were mounted (50\% glycerin and $0.1 \%$ paraphenylenediamine in PBS) and examined under fluorescence microscopy.

Cell counts for loss of cytochrome c. After 5-7 d in the NGF-containing medium, cultured neurons were deprived of NGF in the presence or absence of linopirdine or XE991. Parallel control cultures were deprived of NGF in the presence of protein synthesis inhibitor CHX or the caspase inhibitor BAF (Enzyme Systems Products, Livermore, MO). Forty-eight hours after NGF withdrawal, cultures were fixed and immunostained with anti-cytochrome c antibodies as stated above. Sympathetic neurons maintained with NGF exhibited a punctate staining pattern with anti-cytochrome $\mathrm{c}$ antibodies, and this staining pattern became very diffuse after NGF deprivation (Deshmukh and Johnson, 1998). For each condition, the number of cells that lost the punctate staining pattern for cytochrome c was counted by a blinded observer, from a random sampling of $100-150$ cells.

Microinjections and quantification of cell death. Microinjection of cytochrome $\mathrm{c}$ into sympathetic neurons was performed as described previously (Deshmukh and Johnson, 1998). Briefly, sympathetic neuronal cultures were grown in the appropriate medium on collagen-coated, 35 $\mathrm{mm}$ dishes and then switched to Leibovitz's L-15 medium containing 100 $\mu \mathrm{g} / \mathrm{ml}$ penicillin and $100 \mu \mathrm{g} / \mathrm{ml}$ streptomycin before injection. To identify the injected cells, the injection solution $\left(100 \mathrm{~mm} \mathrm{KCl}\right.$ and $10 \mathrm{~mm} \mathrm{Kp}_{\mathrm{i}}, \mathrm{pH}$ 7.4) contained rhodamine dextran $(4 \mathrm{mg} / \mathrm{ml})$. The solution containing rhodamine dextran with or without cytochrome c $(15 \mathrm{mg} / \mathrm{ml}$, diluted in water and freshly prepared for each experiment) was injected into the cytoplasm of neurons by using Femtotips needles (Eppendorf Inc., Madison, WI). Immediately after the injections, the number of injected viable cells was determined by counting the number of rhodamine-positive cells that had intact, phase-bright cell bodies. Cultures were then switched to the appropriate medium, and, at various time after injections, the num-
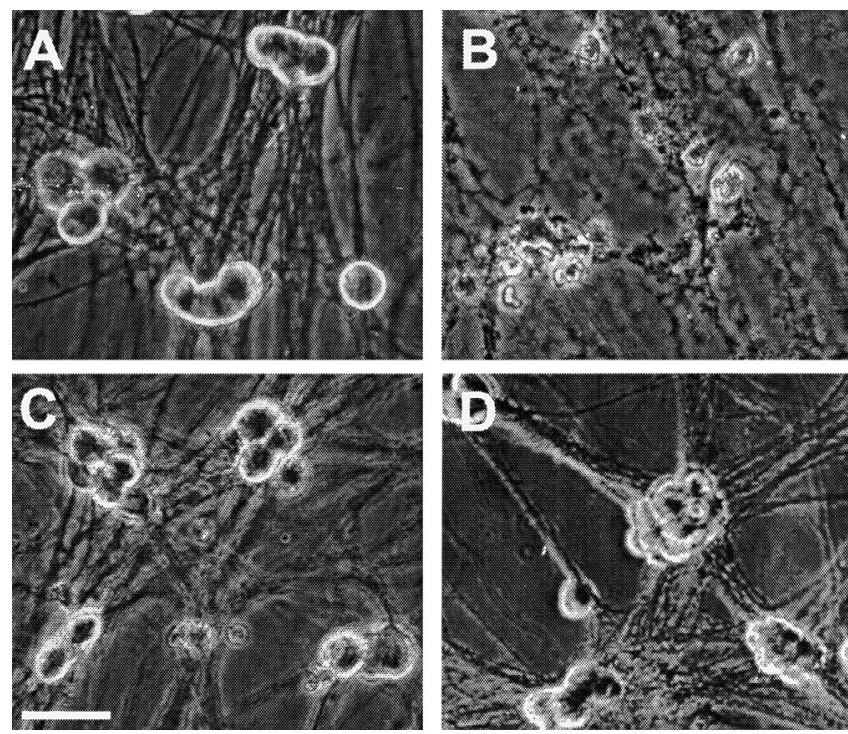

Figure 1. Linopirdine and XE991 promoted survival of sympathetic neurons deprived of NGF. $A$, Healthy sympathetic neurons maintained in the presence of NGF showed phase-bright appearance in phase-contrast photographs. $B$, Cells maintained in NGF for $5 \mathrm{~d}$ after plating and then deprived of NGF for $2 \mathrm{~d}$ had irregular membranes and neurite fragmentation indicative of apoptosis. $C, D$, Neuronal death was prevented in NGF-deprived sympathetic neurons when $20 \mu \mathrm{M}$ linopirdine $(C)$ or $5 \mu \mathrm{M}$ XE991 $(D)$ was added in the medium at the time of NGF withdrawal. Photographs were taken $2 \mathrm{~d}$ after NGF deprivation. Scale bar, $30 \mu \mathrm{m}$. 
ber of remaining viable injected neurons was determined by using the same counting criterion.

Calcium imaging. After $12-16 \mathrm{hr}$ of treatment, we used ratiometric fluorescence imaging with fura-2 AM (Teflabs, Houston, TX) to measure the intracellular free $\mathrm{Ca}^{2+}$ concentration, $\left[\mathrm{Ca}^{2+}\right]_{\mathrm{i}}$, in neuronal cell bodies. Fura- $2 \mathrm{AM}(5 \mu \mathrm{M})$ was bath loaded into neurons at $37^{\circ} \mathrm{C}$ for $1 \mathrm{hr}$, followed by another $1 \mathrm{hr}$ of incubation at room temperature. Fluorescent cells were imaged on an inverted microscope (Diaphot; Nikon, Melville, NY), using a $40 \times, 1.3$ numerical aperture fluorite oil immersion objective (Nikon) and a cooled CCD camera (Sensys; Photometrics, Tucson, AZ). A $75 \mathrm{~W}$ xenon arc lamp provided fluorescence excitation. Ratio images were obtained by acquiring pairs of images at alternate excitation wavelengths ( 340 and $380 \mathrm{~nm}$ ) and filtering the emission at $510 \mathrm{~nm}$. Image acquisition and processing were controlled by a computer connected to the camera and filter wheel (Metafluor; Universal Imaging
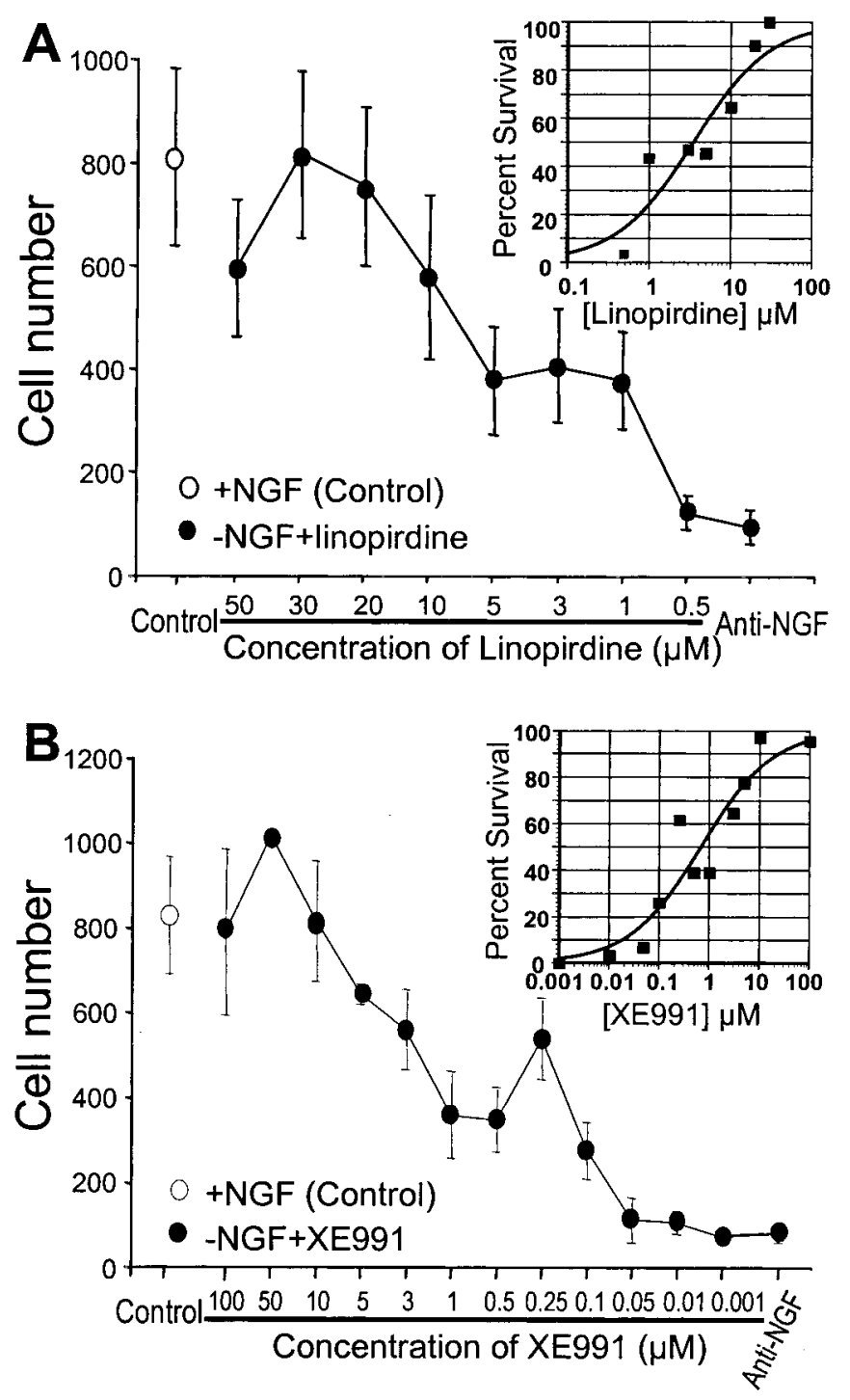

Figure 2. Dose-dependent protective effects of linopirdine and XE991 on sympathetic neuronal apoptosis. Cultures were fixed and stained with toluidine blue, and live cells were counted under a microscope. $A, \mathrm{Li}^{-}$ nopirdine protected sympathetic neurons from apoptosis in a dosedependant manner. At $30 \mu \mathrm{M}$, linopirdine showed the most potent protective effect. The inset is an exponential curve-fitting plot on a log axis; the fitted curve gives an $\mathrm{EC}_{50}$ of $3.5 \mu \mathrm{M}$ for the effect of linopirdine on cell survival. $B, \mathrm{XE} 991$ at $50 \mu \mathrm{M}$ completely protected sympathetic neurons from death. The inset of fitted curve yields an $\mathrm{EC}_{50}$ of $0.7 \mu \mathrm{M}$ for the effect of XE991 on cell survival. Depicted are the mean \pm SEM value for each condition.
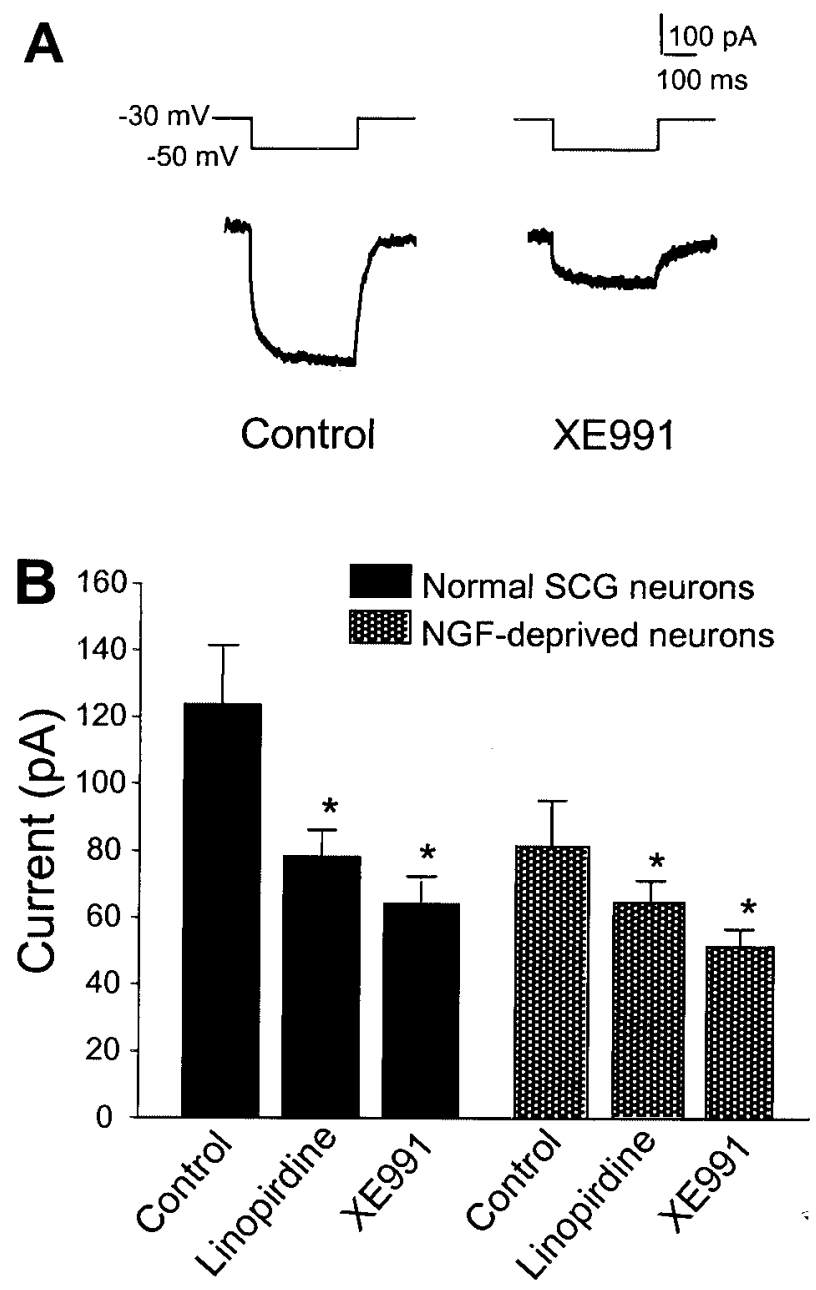

Figure 3. Inhibition of the M current by linopirdine and XE991 in sympathetic neurons. $A$, In whole-cell recording, the membrane potential was held at $-30 \mathrm{mV}$ to allow $\mathrm{M}$ channels to stay in an open state; when the membrane was hyperpolarized to $-50 \mathrm{mV}$, a slow inward current was generated, representing the time-dependent closing of $\mathrm{M}$ channels; during depolarizing back to $-30 \mathrm{mV}$, an outward current associated with channel reopening appeared. After 5 min application of $10 \mu \mathrm{M}$ XE991, the M current was substantially suppressed. $B$, The inhibitory effects of $20 \mu \mathrm{M}$ linopirdine $(n=7)$ and $10 \mu \mathrm{M}$ XE991 $(n=5)$ on M currents in normal sympathetic neurons or neurons deprived of NGF for $7-10 \mathrm{hr} .{ }^{*} p<0.05$ indicates significant difference from the current before drug application (control) (paired $t$ test).

Corporation, West Chester, PA). A background image for each wavelength was acquired from a field lacking fluorescent neurons and subtracted from each fluorescent image.

The actual $\left[\mathrm{Ca}^{2+}\right]_{\mathrm{i}}$ in a region of interest was calculated from the following formula: $\left[\mathrm{Ca}^{2+}\right]_{\mathrm{i}}=K_{\mathrm{d}} B\left(R-R_{\min }\right) /\left(R_{\max }-R\right)$, where $K_{\mathrm{d}}$ is the fura-2 dissociation constant for $\mathrm{Ca}^{2+}(224 \mathrm{nM}), R$ is the average ratio of fluorescence intensity at 340 and $380 \mathrm{~nm}$ wavelength in the region of interest, $R_{\max }$ and $R_{\min }$ are the ratios at saturating $\mathrm{Ca}^{2+}$ and zero $\mathrm{Ca}^{2+}$, respectively, and $B$ is the ratio of the fluorescence intensity of the $380 \mathrm{~nm}$ wavelength at zero and saturating $\mathrm{Ca}^{2+}$ (Grynkiewicz et al., 1985). $R_{\min }$, $R_{\max }$, and $B$ for fura-2 on our microscope were determined by imaging a droplet $(20 \mu \mathrm{l})$ that evenly filled the microscopic field and contained 0 (10 mM EGTA) or $2 \mathrm{~mm}$ added $\mathrm{Ca}^{2+}, 25 \mu \mathrm{M}$ fura- $2 / \mathrm{K}^{+}$, and an artificial intracellular solution. The concentration of fura- 2 in the calibration solution was selected to provide similar fluorescence intensity to that of dye-loaded neurons.

Electrophysiology. Whole-cell recording was used to measure the membrane potential and potassium currents in sympathetic neurons. Neurons were cultured for 7-11 d in $35 \mathrm{~mm}$ dishes and placed on the stage of an inverted microscope (Diaphot; Nikon) that allowed us to record under 

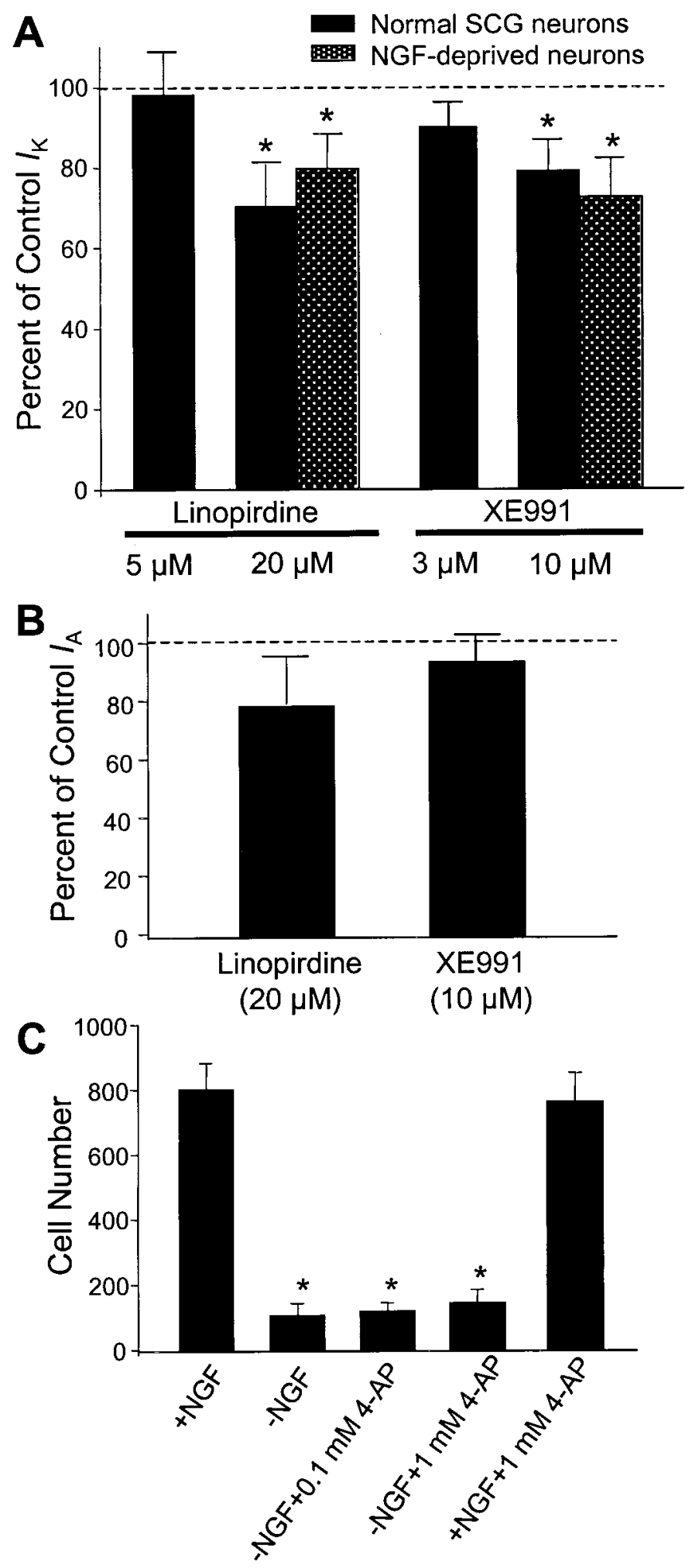

Figure 4. Effects of linopirdine and XE991 on $I_{\mathrm{K}}$ and $I_{\mathrm{A}}$ currents in sympathetic neurons. $A$, The outward delayed rectifier $I_{\mathrm{K}}$ was not affected by $5 \mu \mathrm{M}$ linopirdine and $3 \mu \mathrm{M}$ XE991 added into the medium for up to 20 min. $I_{\mathrm{K}}$ was partly depressed by $20 \mu \mathrm{M}$ linopirdine ( $27 \pm 5 \%$ inhibition; $n=8 ; p<0.05)$ and by $10 \mu \mathrm{M}$ XE991 $(18 \pm 2 \%$ block; $n=8 ; p<0.05)$. Similar inhibitory effects were seen in neurons deprived of NGF for 7-10 $\mathrm{hr}(n=5$ for each test $) . I_{\mathrm{K}}$ was triggered by a voltage step from the holding potential of -70 to $+40 \mathrm{mV}$ for $300 \mathrm{msec}$; steady-state current was measured for the drug effect. ${ }^{*} p<0.05$ indicates significant difference from the control current recorded before drug application. $B$, Linopirdine direct vision. We used an EPC-7 amplifier (List Electronic, Darmstadt, Germany); patch electrodes had tip resistances between 7 and $10 \mathrm{M} \Omega$ (fire polished). The extracellular solution contained (in $\mathrm{mM}$ ): $115 \mathrm{NaCl}$, $2.5 \mathrm{KCl}, 2.0 \mathrm{MnCl}_{2}, 10 \mathrm{HEPES}, 0.1$ BAPTA, and $10 \mathrm{D}$-glucose. Tetrodotoxin (TTX) $(0.1 \mu \mathrm{M})$ was added in some of the experiments. $\mathrm{Mn}^{2+}$ was chosen to replace $\mathrm{Ca}^{2+}$ to block $\mathrm{Ca}^{2+}$ channel activation. The electrode solution contained (in mM): $120 \mathrm{KCl}, 1.5 \mathrm{MgCl}_{2}, 1.0 \mathrm{CaCl}_{2}, 2.0$ $\mathrm{Na}_{2}$-ATP, 1.0 BAPTA, and 10 HEPES. After forming gigaohm seals, whole-cell recording mode was established by slight suctions. Current and voltage traces were displayed and stored on a computer using the data acquisition-analysis program package PULSE (Heka Electronik, Lambrecht/Pfalz, Germany).

Reagents. All reagents were purchased from Sigma (St. Louis, MO) unless otherwise stated. Linopirdine and XE991 were kindly provided by DuPont Pharmaceuticals (Wilmington, DE).

Statistics. Significant changes were determined if the two-tailed $p$ value was at least $<0.05$. Multiple comparisons were performed using one-way ANOVA, followed by Tukey's test using commercial InStat (GraphPad Software Inc., San Diego, CA). Data were represented as mean \pm SEM.

\section{RESULTS}

\section{M channel blockers protected sympathetic neurons from programmed cell death induced by NGF deprivation}

The M channel blocker linopirdine or XE991 showed marked neuroprotection against apoptosis induced by NGF withdrawal. Within $48 \mathrm{hr}$ of NGF deprivation, $90 \%$ of sympathetic neurons underwent apoptosis as indicated by cell shrinkage, phase darkness, irregular membranes, and neurite fragmentation (Fig. 1B). In the presence of linopirdine or XE991, the NGF-deprived neurons maintained their phase-bright appearance and intact neurites and looked similar to neurons in NGF-maintained medium (Fig. $1 A, C, D$ ). The protective effect of both linopirdine and XE991 was concentration dependent (Fig. 2). After $48 \mathrm{hr}$ incubation in NGF-deprived medium, $>90 \%$ of the neurons survived with $30 \mu \mathrm{M}$ linopirdine or $50 \mu \mathrm{M}$ XE991. The $\mathrm{EC}_{50}$ values of linopirdine and XE991 against NGF deprivation-induced cell death were 3.5 and $0.7 \mu \mathrm{M}$, respectively (Fig. 2).

\section{Mediation of the neuroprotection by M-type potassium channels}

The $\mathrm{M}$ channel is a non-inactivating $\mathrm{K}^{+}$channel (Brown and $\mathrm{Yu}$, 2000). Previous work in hippocampal neurons showed that linopirdine blocked the $\mathrm{M}$ current with an $\mathrm{IC}_{50}$ of $2.4 \mu \mathrm{M}$ (Schnee and Brown, 1998). In sympathetic neurons, the $M$ current was blocked by $54 \pm 5 \%$ by $20 \mu \mathrm{M}$ linopirdine $(n=10 ; p<0.05)$ and $62 \pm 8 \%$ by $10 \mu \mathrm{M}$ XE991 $(n=10 ; p<0.05)$ (Fig. 3$)$. At concentrations that blocked approximately half of cell death, linopirdine $(5 \mu \mathrm{M})$ and XE991 $(3 \mu \mathrm{M})$ suppressed $10 \pm 1$ and $15 \pm 1 \%$ M current ( $n=5$ and 7 respectively; $p<0.05)$; at these concentrations, they showed little inhibitory effect on other potassium currents (Fig. 4). Higher concentrations of linopirdine $(20 \mu \mathrm{M})$ and XE991 $(10 \mu \mathrm{M})$, nevertheless, suppressed the outward delayed rectifier $\mathrm{K}^{+}$current $I_{\mathrm{K}}$ (Fig. 4). Neither linopirdine $(20 \mu \mathrm{M})$ nor XE991 $(10 \mu \mathrm{M})$ showed significant inhibitory effect on the A-type $\mathrm{K}^{+}$current, $I_{\mathrm{A}}$, when evaluated at a membrane potential of $-20 \mathrm{mV}$ (Fig. 4). Both drugs did, however, attenuate

$(20 \mu \mathrm{M})$ and XE991 $(10 \mu \mathrm{M})$ showed no significant effect on the A-type $\mathrm{K}^{+}$current triggered by a voltage step from -110 to $-20 \mathrm{mV}$. The $I_{\mathrm{A}}$ peak current was measured for the drug effect ( $n=8$ for each group). $C$, The A-type $\mathrm{K}^{+}$channel blocker 4-AP $(0.1$ and $1.0 \mathrm{~mm})$ showed no protection against the NGF deprivation-induced cell death; 4-AP at tested concentrations was not toxic to SCG neurons. ${ }^{*} p<0.05$ indicates significant difference from controls with NGF. 
$\sim 20-30 \%$ of $I_{\mathrm{A}}$ current triggered by voltage steps to positive membrane potentials $(+20$ or $+40 \mathrm{mV})$. The pharmacological profile of linopirdine and XE991 appeared similar in normal sympathetic neurons or neurons deprived of NGF for 7-10 hr (Figs. 3, 4). The selective $I_{\mathrm{A}}$ channel blocker 4-aminopyridine (4-AP) (0.1 and $1.0 \mathrm{~mm})$ showed no protective effect against the NGF deprivation-induced apoptosis (Fig. 4), supporting our hypothesis that $I_{\mathrm{A}}$ was not involved in the neuroprotection.

In contrast to sympathetic neurons, cortical neurons in our culture condition often do not have detectable M current (Fig. 5). In agreement with this observation, linopirdine (1-10 $\mu \mathrm{M})$ and XE991 (1-10 $\mu \mathrm{M})$ showed no neuroprotective effect against apoptosis in cortical neuronal cultures (Fig. 5).

\section{Linopirdine and XE991 prevented cytochrome c translocation from mitochondria to cytosol}

Because linopirdine and XE991 protected sympathetic neurons from apoptotic cell death under NGF deprivation, we examined whether these compounds blocked the pathway leading to the release of cytochrome $\mathrm{c}$ and/or the development of competenceto-die (Deshmukh and Johnson, 1998). Immunocytochemistry showed that, in NGF-containing medium or in NGF-depleted medium containing $\mathrm{CHX},>90 \%$ of the neurons possessed intact mitochondrial cytochrome $\mathrm{c}$ by exhibiting a punctate staining pattern. Cells deprived of NGF and treated with the caspase inhibitor BAF showed a diff used cytoplasmic pattern (Deshmukh and Johnson, 1998). Cultures treated with linopirdine or XE991 under NGF deprivation retained intact mitochondrial cytochrome $\mathrm{c}$ in over $90 \%$ of the cells (Fig. 6). Therefore, the $\mathrm{K}^{+}$ channel blockers inhibited neuronal apoptosis by acting at a point before the release of cytochrome $\mathrm{c}$ from mitochondria to cytosol.

\section{Linopirdine and XE991 inhibited the competence-to-die of sympathetic neurons}

We then examined whether linopirdine or XE991 prevented sympathetic neuronal apoptosis by inhibiting the development of competence-to-die (Deshmukh and Johnson, 1998). Sympathetic neurons were deprived of NGF in the presence of linopirdine or XE991 for 36-48 hr. Parallel control cultures were deprived of NGF in the presence of cycloheximide. To examine whether these neurons had developed competence-to-die, cells were microinjected with mammalian cytochrome $\mathrm{c}$, and their survival was assessed at multiple time points after cytosolic microinjection with mammalian cytochrome c. As reported previously (Deshmukh and Johnson, 1998), the NGF-deprived, cycloheximidesaved neurons developed "competence," because microinjection of cytochrome c induced rapid cell death in these neurons. In contrast, $>80 \%$ of the linopirdine- or XE991-treated neurons were alive even $12 \mathrm{hr}$ after cytosolic microinjection of cytochrome c (Fig. 7). The fact that microinjection of cytochrome $\mathrm{c}$ did not induce cell death in the presence of linopirdine or XE991 indicates that these neurons, although deprived of NGF, had not developed competence-to-die. Thus, both linopirdine and XE991 appear to block the pathway leading to the development of competence-to-die during NGF deprivation.

\section{Increased intracellular calcium was correlated with sympathetic neuronal survival in NGF deprivation}

Intracellular $\mathrm{Ca}^{2+}$ concentration is critical for survival in some cell death paradigms (Gallo et al., 1987; Collins and Lile, 1989; Koike et al., 1989; Collins et al., 1991; Franklin et al., 1995). We, therefore, investigated whether nifedipine could reduce the capacity of $\mathrm{M}$ channel blockers to promote neuron survival. Nifed-
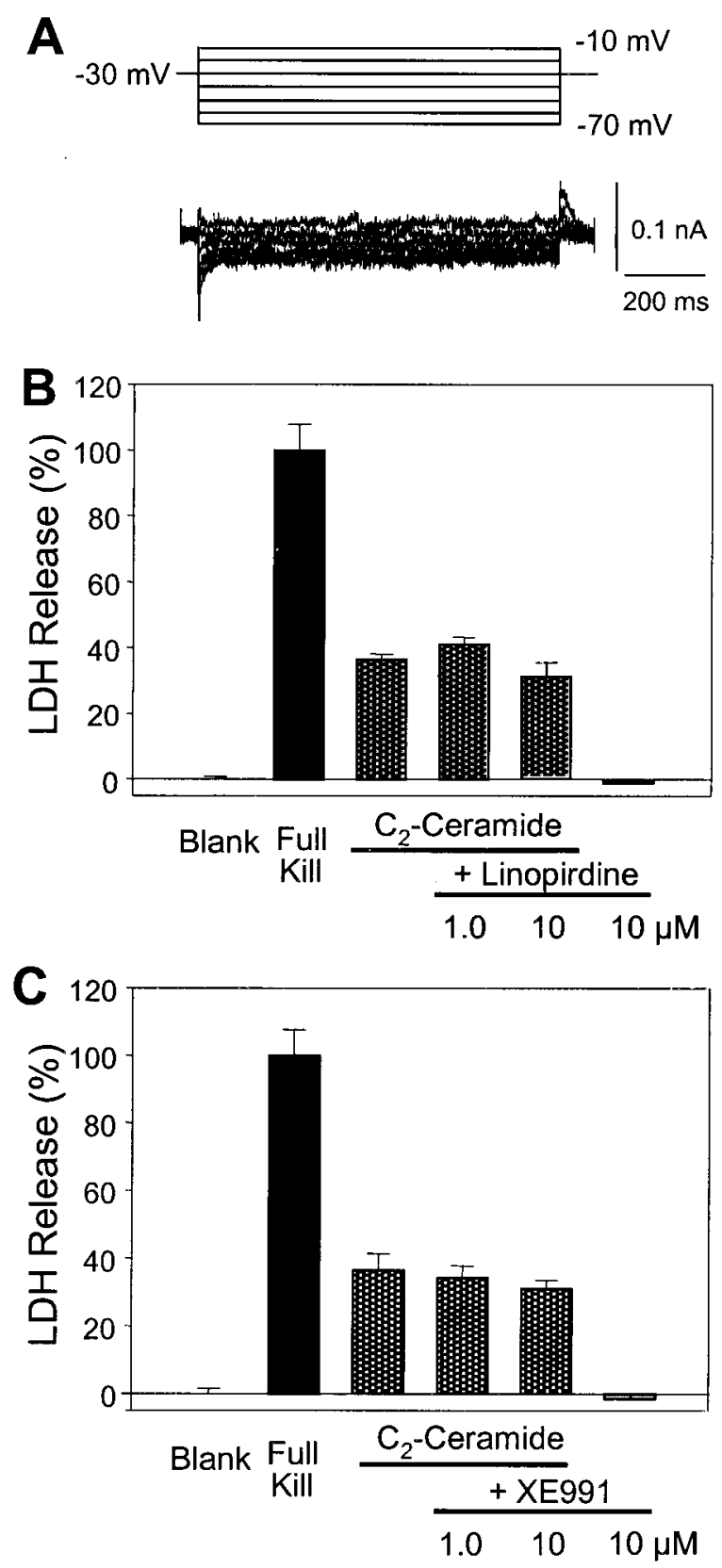

Figure 5. Lack of neuroprotective effects of linopirdine and XE991 in neocortical cultures. $A$, In cultured cortical neurons, little or small $\mathrm{M}$ current was detected, even with voltage steps of wide ranges specific for $\mathrm{M}$ channel activation (Brown and Adams, 1980; Yu, 1995). B, The membrane-permeable sphingomyelin metabolite $\mathrm{C}_{2}$-ceramide produces apoptosis in cortical neurons, which can be attenuated by $\mathrm{K}^{+}$channel blockers TEA and clofilium (Yu et al., 1999). Cortical cultures were exposed to $25 \mu \mathrm{M} \mathrm{C} \mathrm{C}_{2}$-ceramide alone or coapplied with linopirdine or XE991. Cell death was assayed $48 \mathrm{hr}$ later by $\mathrm{LDH}$ release. $\mathrm{The}^{\mathrm{C}_{2}}$ ceramide-induced cell death was not affected by linopirdine $(1-10 \mu \mathrm{M})$; linopirdine alone showed no influence on cell viability $(n=12$ cultures for each test). $C$, XE991 (1-10 $\mu \mathrm{M})$ showed no protective effect on $\mathrm{C}_{2}$ ceramide-induced apoptosis; XE991 alone was not toxic to cortical cells $(n=12$ cultures for each test). MK-801 $(1 \mu \mathrm{M})$ was added into the medium to prevent NMDA receptor-mediated excitotoxicity. Complete neuronal death was achieved by $300 \mu \mathrm{M}$ NMDA in the absence of MK-801. 


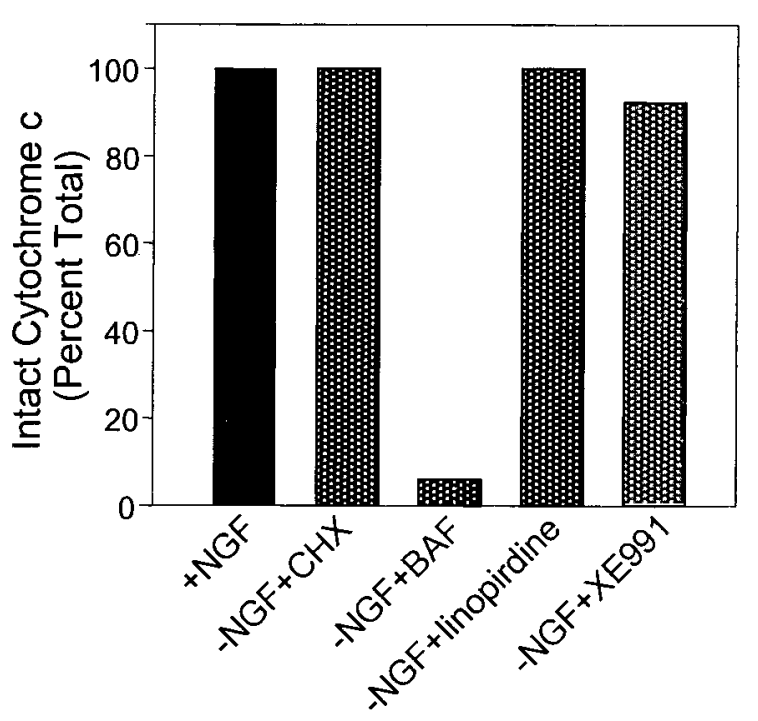

Figure 6. Linopirdine and XE991 prevented cytochrome c release in NGF-deprived sympathetic neurons. Sympathetic neurons were immunostained with anti-cytochrome $\mathrm{c}$ antibody, and the neurons that retained a punctate cytochrome c staining pattern (intact cytochrome c) were counted under different conditions. CHX $(1 \mu \mathrm{g} / \mathrm{ml})$ and BAF $(50 \mu \mathrm{M})$ were used as positive and negative control, respectively. In medium supplemented with linopirdine $(20 \mu \mathrm{M})$ and XE991 $(10 \mu \mathrm{M}),>90 \%$ neurons maintained intact cytochrome $\mathrm{c}$.

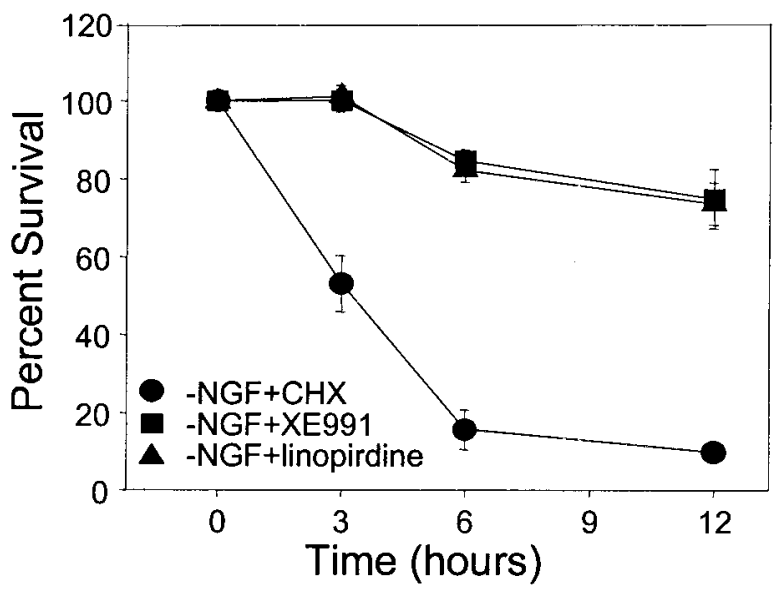

Figure 7. Linopirdine and XE991 inhibited the development of competence-to-die in sympathetic neurons deprived of NGF. Sympathetic neurons were maintained in NGF for $5 \mathrm{~d}$ and then deprived of NGF in the presence of CHX (1 $\mu \mathrm{g} / \mathrm{ml}$; circles), linopirdine (20 $\mu \mathrm{M}$; triangles), or XE991 (10 $\mu \mathrm{M}$; squares) for 36-48 hr. Cells were microinjected with 15 $\mathrm{mg} / \mathrm{ml}$ mammalian cytochrome $\mathrm{c}$. At each time point after the injection, the number of microinjected cells that remained viable was determined and expressed as a percentage of the total number of microinjected cells. Values represent mean \pm SEM. More than $80 \%$ of the linopirdine-saved (triangles) or XE991-saved (squares) neurons were alive, even $12 \mathrm{hr}$ after cytosolic microinjection of cytochrome c. In contrast, the NGF-deprived, cycloheximide-saved neurons (circles) developed competence as microinjection of cytochrome $\mathrm{c}$ induced rapid neuronal death.

ipine dramatically reversed the protective effect of linopirdine and XE991 (Fig. 8). When nifedipine (100 nM) was added together with linopirdine $(30 \mu \mathrm{M})$ or XE991 $(50 \mu \mathrm{M})$ in NGFdeficient medium, the protective effect of these $\mathrm{K}^{+}$channel blockers was reduced by $\sim 80 \%$. Furthermore, nifedipine mostly reduced cell survival promoted by $40 \mathrm{mM} \mathrm{K}^{+}$in NGF-deprived

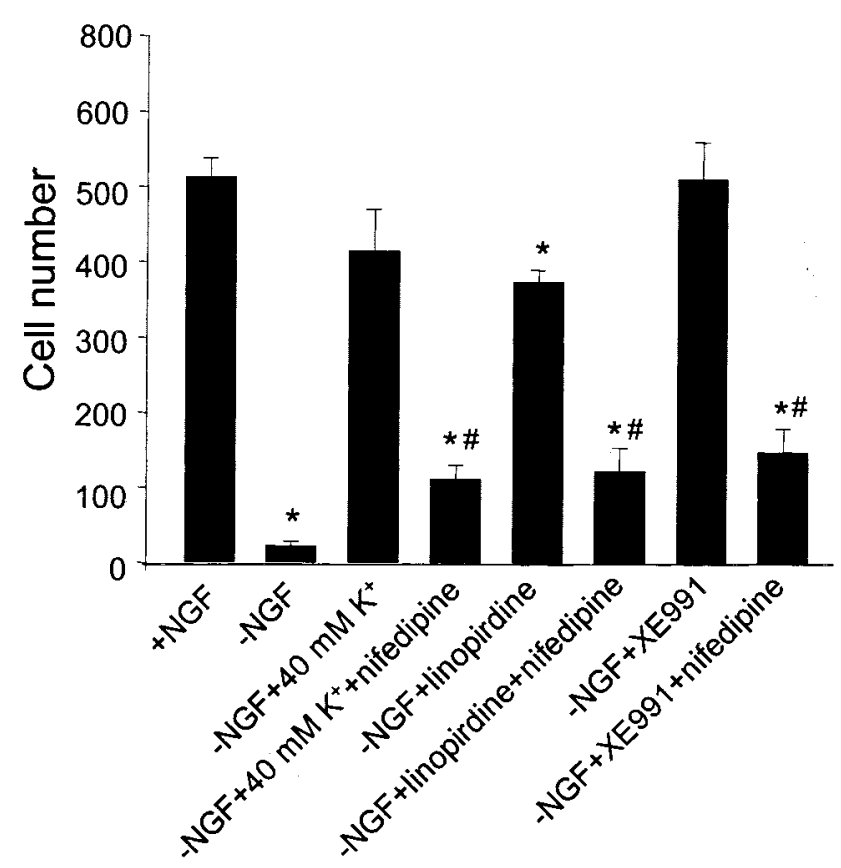

Figure 8. Nifedipine reversed the protective effect of linopirdine or XE991 on NGF-deprived sympathetic neurons. Withdrawal of NGF from the culture medium for $2 \mathrm{~d}$ caused widespread neuronal death. Elevation of extracellular $\mathrm{K}^{+}, 30 \mu \mathrm{M}$ linopirdine, or $50 \mu \mathrm{M} \mathrm{XE991} \mathrm{at} \mathrm{the} \mathrm{time} \mathrm{of}$ NGF deprivation all show prominent neuroprotection. The L-type $\mathrm{Ca}^{2+}$ channel antagonist nifedipine (100 nM) was able to primarily reverse the neuroprotective effects induced by these three treatments. Cell survival was assayed $48 \mathrm{hr}$ after incubation, cells were stained with toluidine blue, and live cells were counted. Significant difference was determined with one-way ANOVA, followed by Tukey's test. * $p<0.001$ indicates significant difference from the control group with NGF; $\# p<0.001$ indicates significant difference from the corresponding group of deprived NGF plus the treatment without nifedipine (i.e., the bar on the left). $n=8$ cultures for each testing group.

medium; the survival rate decreased from 80 to $20 \%$ in the presence of nifedipine.

To better understand the role of $\mathrm{Ca}^{2+}$ in neuronal survival of NGF deprivation, we next examined alterations in $\left[\mathrm{Ca}^{2+}\right]_{i}$ after NGF deprivation. After $12 \mathrm{hr}$ treatment, NGF-deprived neurons showed a statistically insignificant small decline in $\left[\mathrm{Ca}^{2+}\right]_{\mathrm{i}} \mathrm{com}-$ pared with neurons maintained in NGF. However, there was a significant increase in $\left[\mathrm{Ca}^{2+}\right]_{\mathrm{i}}$ in the presence of linopirdine $(20$ $\mu \mathrm{M})$ or XE991 $(10 \mu \mathrm{M})$ over $12 \mathrm{hr}$ in the NGF-deprived medium. The magnitude of the $\left[\mathrm{Ca}^{2+}\right]_{\mathrm{i}}$ increase produced by linopirdine or XE991 was even greater when NGF was present (Fig. 9). The $\left[\mathrm{Ca}^{2+}\right]_{\mathrm{i}}$ elevation induced by either linopirdine or XE991 was prevented by the L-type $\mathrm{Ca}^{2+}$ channel antagonist nifedipine (100 nM) (Fig. 9). On the other hand, the A-type $\mathrm{K}^{+}$channel blocker 4-AP (0.1 mM, 10-70 min) did not elevate $\left[\mathrm{Ca}^{2+}\right]_{\mathrm{i}}$; $\left[\mathrm{Ca}^{2+}\right]_{\mathrm{i}}$ was $20 \pm 4$ and $9 \pm 1 \mathrm{~nm}$ in control and 4-AP-treated cells, respectively ( $n=55$ cells for each group; $p<0.05$ ).

\section{Effect of linopirdine and XE991 on membrane potential}

To understand the mechanism by which the $\mathrm{M}$ channel blockers elevated $\left[\mathrm{Ca}^{2+}\right]_{\mathrm{i}}$, we determined the effect of linopirdine and XE991 on resting membrane potential. When the membrane potential was measured using whole-cell current clamp in the absence of TTX, frequent action potentials were generated after application of linopirdine and XE991 (data not shown). After 30-60 min exposure, the membrane potential was depolarized 


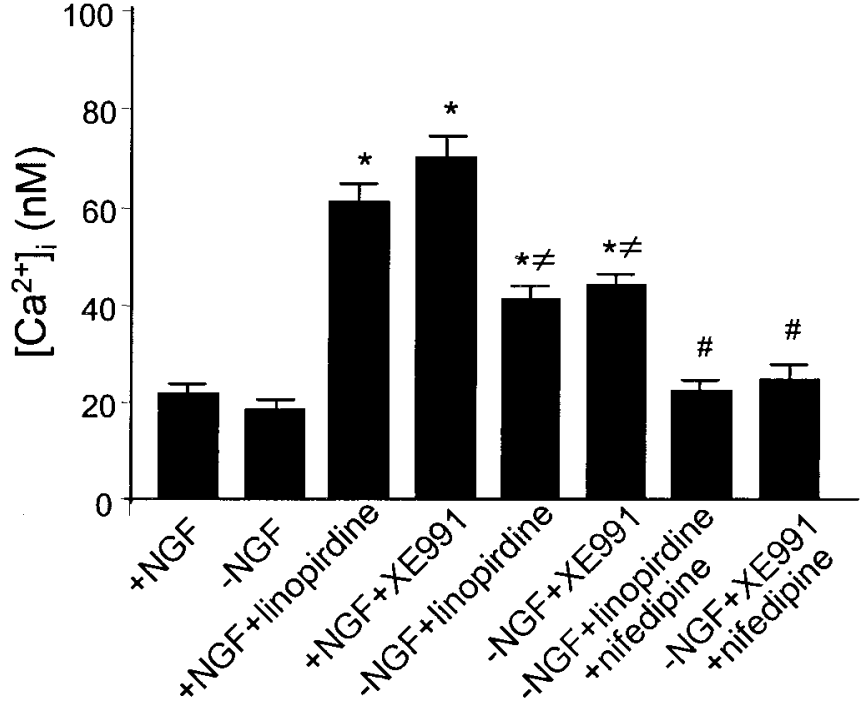

Figure 9. Increases in intracellular free $\mathrm{Ca}^{2+}$ by linopirdine and XE991 and prevention by nifedipine. NGF withdrawal did not cause a significant change in $\left[\mathrm{Ca}^{2+}\right]_{\mathrm{i}}$ measured by fura-2 imaging. In NGF-deprived medium, linopirdine $(20 \mu \mathrm{M})$ or XE991 $(10 \mu \mathrm{M})$ raised $\left[\mathrm{Ca}^{2+}\right]_{\mathrm{i}}$ approximately twofold beyond the baseline. In NGF-maintained medium, $\left[\mathrm{Ca}^{2+}\right]_{\mathrm{i}}$ was increased approximately threefold above the baseline by the same concentration of linopirdine or XE991. The increase in $\left[\mathrm{Ca}^{2+}\right]_{i}$ was eliminated by coapplied nifedipine $(100 \mathrm{nM})$. Data were taken from at least 100 cells. ${ }^{*} p<0.001$ indicates significant difference from the basal level of $\left[\mathrm{Ca}^{2+}\right]_{\mathrm{i}} ; \neq p<0.001$ indicates significant difference from the corresponding group with NGF; $\# p<0.001$ indicates significant difference from the corresponding group without nifedipine.
A

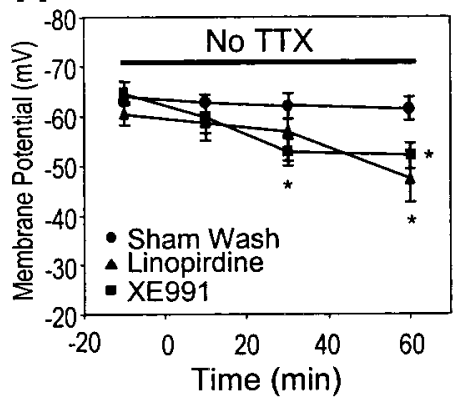

B

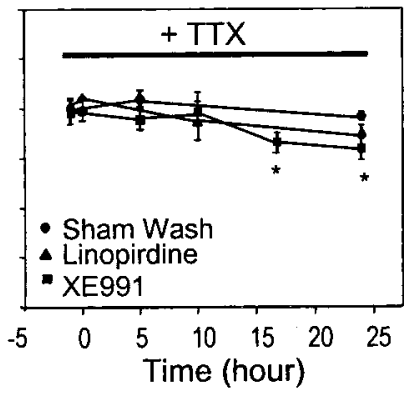

Figure 10. Effects of linopirdine and XE991 on membrane potential of sympathetic neurons and their dependence on activation of $\mathrm{Na}^{+}$channels. Sympathetic neurons were patched at multiple time points for recording of membrane potentials during 1-24 hr treatments. $A$, Neurons were treated with sham wash or exposed to $20 \mu \mathrm{M}$ linopirdine or $10 \mu \mathrm{M}$ XE991 for 10-60 min in the absence of TTX. Compared with the membrane potential before drug application or the time-matched controls, linopirdine and XE991 induced mild but significant depolarization after 30-60 min incubation ( $n=3-10$ cells for each time point). $B$, When TTX (100 nM) was added into the medium, there was no significant difference of membrane potential between sham wash and linopirdinetreated cells during several hours of incubation. Prolonged incubation of up to $24 \mathrm{hr}$ with XE991 induced a mild depolarization $(n=10-20$ cells for each time point). Data shown in plots are from actual time points. ${ }^{*} p<0.05$ versus sham washing at same time point; unpaired $t$ test.

from $-60.3 \pm 2.3$ to $-47.3 \pm 4.7 \mathrm{mV}(p<0.05)$ by linopirdine $(20 \mu \mathrm{M})$ and from $-64.6 \pm 2.3$ to $-52.7 \pm 2.8 \mathrm{mV}(p<0.05)$ by XE991 $(10 \mu \mathrm{M})$, respectively (Fig. 10). The activity of $\mathrm{Na}^{+}$ channels seemed critical for linopirdine- and XE991-induced depolarization. When TTX (100 nM) was coapplied to block $\mathrm{Na}^{+}$
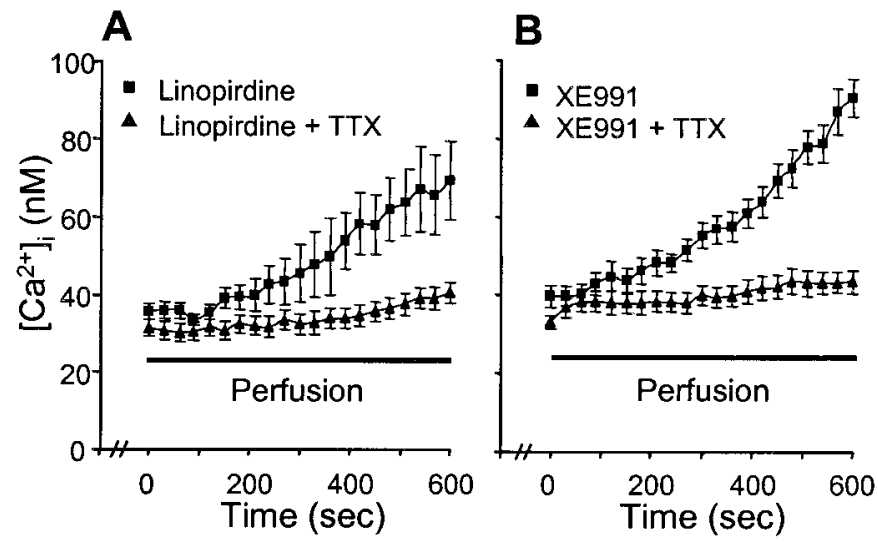

Figure 11. Effects of linopirdine and XE991 on $\left[\mathrm{Ca}^{2+}\right]_{\mathrm{i}}$ and their dependence on activation of $\mathrm{Na}^{+}$channels. Effects of linopirdine and XE991 on $\left[\mathrm{Ca}^{2+}\right]_{\mathrm{i}}$ in sympathetic neurons were tracked by fura- 2 imaging in the presence (triangles) and absence (squares) of TTX. $A$, Linopirdine $(20 \mu \mathrm{M})$ alone caused a gradual increase in $\left[\mathrm{Ca}^{2+}\right]_{\mathrm{i}}(n=12$ cells $)$; the $\left[\mathrm{Ca}^{2+}\right]_{\mathrm{i}}$ increase was prevented by coapplied TTX $(100 \mathrm{nM} ; n=14) . B$, $\left[\mathrm{Ca}^{2+}\right]_{\mathrm{i}}$ was raised by XE991 $(10 \mu \mathrm{M} ; n=10)$, and the effect was blocked by TTX $(100 \mathrm{nM} ; n=7)$.

channels, neither linopirdine nor XE991 altered the resting membrane potential, even after several hours of incubation (Fig. 10). Whereas prolonged incubation of 16-24 hr with XE991 (10 $\mu \mathrm{M})$ and TTX slightly depolarized the membrane, prolonged incubation with linopirdine $(20 \mu \mathrm{M})$ failed to induce any depolarization in the presence of TTX (Fig. 10).

To test the contribution of $\mathrm{Na}^{+}$channel activation to $\mathrm{Ca}^{2+}$ homeostasis, we measured changes in $\left[\mathrm{Ca}^{2+}\right]_{\mathrm{i}}$ after acute application $(60 \mathrm{~min})$ of linopirdine $(20 \mu \mathrm{M})$ or XE991 $(10 \mu \mathrm{M})$ in the presence or absence of TTX (100 nM). TTX diminished the linopirdine-induced or XE991-induced $\left[\mathrm{Ca}^{2+}\right]_{\mathrm{i}}$ elevations, stabilizing $\left[\mathrm{Ca}^{2+}\right]_{\mathrm{i}}$ at or near normal range during the incubation (Fig. 11). Consistent with the $\left[\mathrm{Ca}^{2+}\right]_{\mathrm{i}}$ data, the neuroprotective effects of either linopirdine or XE991 were prevented by coapplied TTX (Fig. 12).

\section{DISCUSSION}

The experiments described above demonstrate that $\mathrm{K}^{+}$channel blockers targeting the M-type channel strongly promote sympathetic neuronal survival by activating voltage-gated $\mathrm{Na}^{+}$and $\mathrm{Ca}^{2+}$ channels and increasing $\left[\mathrm{Ca}^{2+}\right]_{\mathrm{i}}$. We further reveal that interactions of these ion channels contribute to the neuroprotection observed in sympathetic neurons.

\section{Membrane depolarization and activation of voltage-gated channels in the neuroprotection}

The membrane depolarization caused by linopirdine and XE991 was magnified by activation of voltage-gated $\mathrm{Na}^{+}$channels. Although we anticipated that these drugs would block membrane $\mathrm{K}^{+}$channels and depolarize the neurons directly, we saw little evidence for a membrane depolarization induced directly by blocking $\mathrm{M}$ channels. The small decrease in membrane potential in the presence of TTX was insufficient to open voltage-gated calcium channels (Franklin et al., 1995). Therefore, it appears that block of $\mathrm{M}$ channels by linopirdine and XE991 requires activation of $\mathrm{Na}^{+}$channels to amplify the depolarization and, consequently, to promote $\mathrm{Ca}^{2+}$ entry via the L-type $\mathrm{Ca}^{2+}$ channel and neuron survival. The interdependence between activation of $\mathrm{Ca}^{2+}$ and $\mathrm{Na}^{+}$channels in neuronal death and survival has also been reported after traumatic axonal injury, in which $\mathrm{Na}^{+}$ 


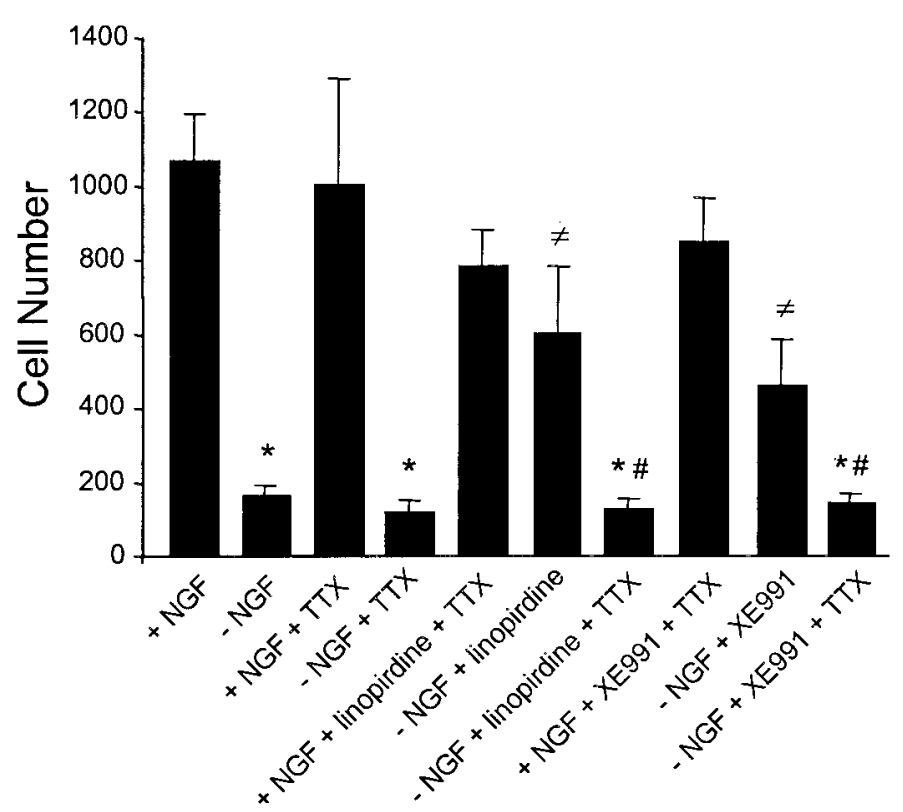

Figure 12. Requirement of $\mathrm{Na}^{+}$channel activation in the protective effect of linopirdine and XE991 on sympathetic neurons deprived of NGF. Substantial neuronal death was induced by 2 d NGF withdrawal. In the presence or absence of NGF, TTX (100 nM) alone showed little influence on cell survival. Addition of $30 \mu \mathrm{M}$ linopirdine or $50 \mu \mathrm{M}$ XE991 promoted cell survival in the absence of NGF; $100 \mathrm{nM}$ TTX abolished the neuroprotection induced by linopirdine or XE991. Cell survival was assayed $48 \mathrm{hr}$ after incubation, cells were stained with toluidine blue, and live cells were counted. $n=4$ cultures for each group. ${ }^{*} p<0.001$ indicates significant difference from the control with NGF; $\neq p<0.05$ indicates significant difference from NGF deprived cells without antagonist; \#p < 0.05 indicates significant difference from the corresponding group without TTX (i.e., the next bar on the left).

influx could subsequently trigger an increase in $\left[\mathrm{Ca}^{2+}\right]_{\mathrm{i}}$ via the opening of voltage-gated $\mathrm{Ca}^{2+}$ channels and reversal of the $\mathrm{Na}^{+}-\mathrm{Ca}^{2+}$ exchanger (Wolf et al., 2001).

Roles of calcium and potassium in the neuroprotection The precise cellular mechanism(s) used by $\left[\mathrm{Ca}^{2+}\right]_{i}$ to enhance neuronal survival remain elusive. Translocation of cytochrome $\mathrm{c}$ and development of competence-to-die could be directly inhibited by elevated $\left[\mathrm{Ca}^{2+}\right]_{\mathrm{i}}$ (Putcha et al., 1999). We found that both linopirdine and XE991 block the pathways leading to the release of cytochrome c and the development of competence-to-die in sympathetic neurons under NGF deprivation. This is consistent with previous observations that depolarization with elevated extracellular $\mathrm{K}^{+}$could block the release of cytochrome $\mathrm{c}$ and development of competence-to-die (Putcha et al., 1999). On the other hand, we are also intrigued by the observation that $\left[\mathrm{Ca}^{2+}\right]_{\mathrm{i}}$ does not seem to decrease significantly after NGF is withdrawn for 12-16 hr (Franklin et al., 1995) (Fig. 9). This suggests that NGF does not necessarily maintain $\left[\mathrm{Ca}^{2+}\right]_{i}$; rather, manipulations that elevate $\left[\mathrm{Ca}^{2+}\right]_{\mathrm{i}}$ above normal levels are capable of substituting for the removal of the NGF. Consequently, two separate trophic pathways may be present in the sympathetic neurons: one requiring $\mathrm{NGF}$ and one dependent on elevated $\left[\mathrm{Ca}^{2+}\right]_{\mathrm{i}}$. Very large elevations in $\left[\mathrm{Ca}^{2+}\right]_{\mathrm{i}}$ are neurotoxic, but these are well above the levels seen in the protected sympathetic neurons (Hyrc et al., 1997).

The $\mathrm{K}^{+}$hypothesis for apoptosis has been proposed based on observations that an excessive $\mathrm{K}^{+}$efflux and intracellular $\mathrm{K}^{+}$ depletion are early events in apoptotic cascade and prerequisites for apoptotic shrinkage, caspase-3 cleavage, and endonuclease activation (McCarthy and Cotter, 1997; Yu et al., 1997; Dallaporta et al., 1998; Hughes and Cidlowski, 1999). The $\mathrm{K}^{+}$mechanism of apoptosis has been implicated in cortical (Yu et al., 1997, 1998, 1999), hippocampal (Nadeau et al., 2000), and basal forebrain cholinergic neurons (Colom et al., 1998), as well as in peripheral cells such as lymphocytes (Dallaporta et al., 1998; Hughes and Cidlowski, 1999). In the present study, although nifedipine maintained $\left[\mathrm{Ca}^{2+}\right]_{\mathrm{i}}$ at the resting level, it did not completely eliminate the neuroprotection by linopirdine and XE991. It is possible that the residual $\pm 20 \%$ neuronal survival is attributable to attenuated $\mathrm{K}^{+}$efflux. This might also explain the report that $\mathrm{Na}^{+}$channel activation delays sympathetic neuronal death induced by NGF deprivation in the absence of calcium entry (Tanaka and Koike, 1997). In this situation, $\mathrm{Na}^{+}$entry might enhance the activity of the $\mathrm{Na}^{+}, \mathrm{K}^{+}$-ATPase and preserve levels of intracellular $\mathrm{K}^{+}$.

Based on available evidence, we currently believe that intracellular $\mathrm{Ca}^{2+}$ and $\mathrm{K}^{+}$both contribute to regulation of neuronal apoptosis; the dominant mechanism, however, may be different depending on the cell types and apoptotic pathways involved ( $\mathrm{Yu}$ et al., 2001). Specifically, the $\mathrm{Ca}^{2+}$-dependent mechanism is likely the principal mechanism for the protection against NGF deprivation-induced apoptosis in sympathetic neurons.

\section{M-type potassium channel block and anti-apoptotic neuroprotection}

The $\mathrm{M}$ channel is a $\mathrm{G}$-protein-coupled $\mathrm{K}^{+}$channel inhibited by muscarinic cholinergic agonists, originally described in bullfrog sympathetic neurons (Brown and Adams, 1980). It is a voltageand time-dependent, low-threshold, non-inactivating channel, and the primary $\mathrm{K}^{+}$channel activated near the threshold for $\mathrm{Na}^{+}$ channel activation and generation of action potentials. The $\mathrm{M}$ channel, thus, plays important roles in determining the membrane potential and membrane excitability. Our study is the first report of an anti-apoptotic effect associated with antagonism of this $\mathrm{K}^{+}$ channel. We conclude that the neuroprotection achieved by linopirdine and XE991 is mainly attributable to inhibition of the M channel based on the following observations: (1) the half effective concentrations for $\mathrm{M}$ current block and neuroprotection are both in low micromolar range; (2) at concentrations that prevented $\sim 50 \%$ neuronal death, linopirdine and XE991 show no significant effect on other $\mathrm{K}^{+}$currents; and (3) linopirdine and XE991 have little anti-apoptotic effect in cultured cortical neurons that have most major $\mathrm{K}^{+}$currents but lack the $\mathrm{M}$ current. On the other hand, because these two compounds inhibit $I_{\mathrm{K}}$ at high concentrations, their powerful neuroprotection at these concentrations could involve block of $I_{\mathrm{K}}$ and even other $\mathrm{K}^{+}$currents (Schnee and Brown, 1998). We did not test the effects of low concentrations of linopirdine and XE991 on cytochrome c release and $\left[\mathrm{Ca}^{2+}\right]_{\mathrm{i}}$ increase; however, based on their concentration-dependent neuroprotective effects against apoptosis, it is reasonable to predict that these two cellular events are likely affected by linopirdine and XE991 in concentrationdependent manners.

\section{Final remarks}

The complicated interaction of several voltage-gated channels leading to neuroprotection in these experiments was a surprise to us, knowing that other investigators described previously exacerbation of neuronal death by activation of voltage-gated $\mathrm{Na}^{+}$ 
channels (Koike et al., 2000). Our results illustrate the complex interrelationship between ion channel activities and suggest that synchronized manipulation of $\mathrm{K}^{+}, \mathrm{Ca}^{2+}$, and $\mathrm{Na}^{+}$channel activities may be necessary for a neuroprotective reagent in a specific paradigm. Given the potency and specificity of the two M-type $\mathrm{K}^{+}$channel antagonists used in the present study, we predict that these or similar drugs may offer a more practical approach to $\mathrm{K}^{+}$channel blockade as a neuroprotective strategy than elevation of extracellular $\mathrm{K}^{+}$or administration of lower potency and less selective $\mathrm{K}^{+}$channel antagonists.

\section{REFERENCES}

Brown BS, Yu SP (2000) Modulation and genetic identification of the M channel. Prog Biophys Mol Biol 73:135-166.

Brown DA, Adams PR (1980) Muscarinic suppression of a novel voltage-sensitive $\mathrm{K}^{+}$current in a vertebrate neurone. Nature 283:673-676.

Choi DW (1996) Ischemia-induced neuronal apoptosis. Curr Opin Neurobiol 6:667-672.

Collins F, Lile JD (1989) The role of dihydropyridine-sensitive voltagegated calcium channels in potassium-mediated neuronal survival. Brain Res 502:99-108.

Collins F, Schmidt MF, Guthrie PB, Kater SB (1991) Sustained increase in intracellular calcium promotes neuronal survival. J Neurosci 11:2582-2587.

Colom LV, Diaz ME, Beers DR, Neely A, Xie WJ, Appel SH (1998) Role of potassium channels in amyloid-induced cell death. J Neurochem 70:1925-1934.

Costa AM, Brown BS (1997) Inhibition of M-current in cultured rat superior cervical ganglia by linopirdine: mechanism of action studies. Neuropharmacology 36:1747-1753.

Dallaporta B, Hirsch T, Susin SA, Zamzami N, Larochette N, Brenner C, Marzo I, Kroemer G (1998) Potassium leakage during the apoptotic degradation phase. J Immunol 160:5605-5615.

Deckwerth TL, Johnson EM (1993) Temporal analysis of events associated with programmed cell death (apoptosis) of sympathetic neurons deprived of nerve growth factor. J Cell Biol 123:1207-1222.

Deshmukh M, Johnson EM (1997) Programmed cell death in neurons: focus on the pathway of nerve growth factor deprivation-induced death of sympathetic neurons. Mol Pharmacol 51:897-906.

Deshmukh M, Johnson EM (1998) Evidence of a novel event during neuronal death: development of competence-to-die in response to cytoplasmic cytochrome c. Neuron 21:695-705.

Deshmukh M, Vasilakos J, Deckwerth TL, Lampe PA, Shivers BD, Johnson EM (1996) Genetic and metabolic status of NGF-deprived sympathetic neurons saved by an inhibitor of ICE family proteases. J Cell Biol 135:1341-1354.

Easton RM, Deckwerth TL, Parsadanian AS, Johnson EM (1997) Analysis of the mechanism of loss of trophic factor dependence associated with neuronal maturation: a phenotype indistinguishable from Bax deletion. J Neurosci 17:9656-9666.

Edwards SN, Buckmaster AE, Tolkovsky AM (1991) The death programme in cultured sympathetic neurones can be suppressed at the posttranslational level by nerve growth factor, cyclic AMP, and depolarization. J Neurochem 57:2140-2143.

Franklin JL, Sanz-Rodriguez C, Juhasz A, Deckwerth TL, Johnson EM (1995) Chronic depolarization prevents programmed death of sympathetic neurons in vitro but does not support growth: requirement for $\mathrm{Ca}^{2+}$ influx but not Trk activation. J Neurosci 15:643-664.

Galli C, Meucci O, Scorziello A, Werge TM, Calissano P, Schettini G (1995) Apoptosis in cerebellar granule cells is blocked by high $\mathrm{KCl}$, forskolin, and IGF-1 through distinct mechanisms of action: the involvement of intracellular calcium and RNA synthesis. J Neurosci 15:1172-1179.

Gallo V, Kingsbury A, Balazs R, Jorgensen OS (1987) The role of depolarization in the survival and differentiation of cerebellar granule cells in culture. J Neurosci 7:2203-2213.

Grynkiewicz G, Poenie M, Tsien RY (1985) A new generation of $\mathrm{Ca}^{2+}$ indicators with greatly improved fluorescence properties. J Biol Chem 260:3440-3450.

Henderson CE (1996) Programmed cell death in the developing nervous system. Neuron 17:579-585.

Hughes FM, Cidlowski JA (1999) Potassium is a critical regulator of apoptotic enzymes in vitro and in vivo. Adv Enzyme Regul 39:157-171.

Hyrc K, Handran SD, Rothman SM, Goldberg MP (1997) Ionized intracellular calcium concentration predicts excitotoxic neuronal death: observations with low-affinity fluorescent calcium indicators. J Neurosci $17: 6669-6677$
Johnson MI, Argiro V (1983) Techniques in the tissue culture of rat sympathetic neurons. Methods Enzymol 103:334-347.

Koike T, Martin DP, Johnson EM (1989) Role of $\mathrm{Ca}^{2+}$ channels in the ability of membrane depolarization to prevent neuronal death induced by trophic-factor deprivation: evidence that levels of internal $\mathrm{Ca}^{2+}$ determine nerve growth factor dependence of sympathetic ganglion cells. Proc Natl Acad Sci USA 86:6421-6425.

Koike T, Tanaka S, Oda1 T, Ninomiya T (2000) Sodium overload through voltage-dependent $\mathrm{Na}^{+}$channels induces necrosis and apoptosis of rat superior cervical ganglion cells in vitro. Brain Res Bull 51:345-355.

Kristufek D, Koth G, Motejlek A, Schwarz K, Huck S, Boehm S (1999) Modulation of spontaneous and stimulation-evoked transmitter release from rat sympathetic neurons by the cognition enhancer linopirdine: insights into its mechanisms of action. J Neurochem 72:2083-2091.

Martin DP, Schmidt RE, DiStefano PS, Lowry OH, Carter JG, Johnson EM (1988) Inhibitors of protein synthesis and RNA synthesis prevent neuronal death caused by nerve growth factor deprivation. J Cell Biol 106:829-844.

McCarthy JV, Cotter TG (1997) Cell shrinkage and apoptosis: a role for potassium and sodium ion efflux. Cell Death Differ 4:756-770.

McCarthy MJ, Rubin LL, Philpott KL (1997) Involvement of caspases in sympathetic neuron apoptosis. J Cell Sci 110:2165-2173.

Nadeau H, McKinney S, Anderson DJ, Lester HA (2000) ROMK1 (Kir1.1) causes apoptosis and chronic silencing of hippocampal neurons. J Neurophysiol 84:1062-1075.

Oppenheim RW (1991) Cell death during development of the nervous system. Annu Rev Neurosci 14:453-501.

Pike CJ, Balazs R, Cotman CW (1996) Attenuation of beta-amyloid neurotoxicity in vitro by potassium-induced depolarization. J Neurochem 67:1774-1777.

Putcha GV, Deshmukh M, Johnson EM (1999) BAX translocation is a critical event in neuronal apoptosis: regulation by neuroprotectants, BCL-2, and caspases. J Neurosci 19:7476-7485.

Rose K, Goldberg MP, Choi DW (1993) Cytotoxicity in murine cortical cell culture. In: Methods in toxicology, Vol 1, Pt A, In vitro biological methods, pp 46-60. San Diego: Academic.

Rydel RE, Greene LA (1988) cAMP analogs promote survival and neurite outgrowth in cultures of rat sympathetic and sensory neurons independently of nerve growth factor. Proc Natl Acad Sci USA 85:1257-1261.

Schnee ME, Brown BS (1998) Selectivity of linopirdine (DuP 996), a neurotransmitter release enhancer, in blocking voltage-dependent and calcium-activated potassium currents in hippocampal neurons. J Pharmacol Exp Ther 286:709-717.

Tanaka S, Koike T (1997) Veratridine delays apoptotic neuronal death induced by $\mathrm{NGF}$ deprivation through a $\mathrm{Na}^{+}$-dependent mechanism in cultured rat sympathetic neurons. Int J Dev Neurosci 15:15-27.

Tong JX, Vogelbaum MA, Drzymala RE, Rich KM (1997) Radiationinduced apoptosis in dorsal root ganglion neurons. J Neurocytol 26:771-777.

Wang HS, Pan Z, Shi W, Brown BS, Wymore RS, Cohen IS, Dixon JE, McKinnon D (1998) KCNQ2 and KCNQ3 potassium channel subunits: molecular correlates of the M-channel. Science 282:1890-1893.

Wang HS, Brown BS, McKinnon D, Cohen IS (2000) Molecular basis for differential sensitivity of $\mathrm{KCNQ}$ and $\mathrm{I}_{\mathrm{K}_{\mathrm{s}}}$ channels to the cognitive enhancer XE991. Mol Pharmacol 57:1218-1223.

Werth JL, Deshmukh M, Cocabo J, Johnson EM, Rothman SM (2000) Reversible physiological alterations in sympathetic neurons deprived of NGF but protected from apoptosis by caspase inhibition or Bax deletion. Exp Neurol 161:203-211.

Wolf JA, Stys PK, Lusardi T, Meaney D, Smith DH (2001) Traumatic axonal injury induces calcium influx modulated by tetrodotoxinsensitive sodium channels. J Neurosci 21:1923-1930.

Yu SP (1995) Roles of arachidonic acid, lipoxygenases and phosphatases in calcium-dependent modulation of M-current in bullfrog sympathetic neurons. J Physiol (Lond) 487:797-811.

Yu SP, Yeh CH, Sensi SL, Gwag BJ, Canzoniero LM, Farhangrazi ZS, Ying HS, Tian M, Dugan LL, Choi DW (1997) Mediation of neuronal apoptosis by enhancement of outward potassium current. Science 278:114-117.

Yu SP, Farhangrazi ZS, Ying HS, Yeh CH, Choi DW (1998) Enhancement of outward potassium current may participate in beta-amyloid peptide-induced cortical neuronal death. Neurobiol Dis 5:81-88.

Yu SP, Yeh CH, Gottron F, Wang X, Grabb MC, Choi DW (1999) Role of the outward delayed rectifier $\mathrm{K}^{+}$current in ceramide-induced caspase activation and apoptosis in cultured cortical neurons. J Neurochem 73:933-941.

Yu SP, Canzoniero LMT, Choi DW (2001) Ion homeostasis and apoptosis. Cur Opin Cell Biol 13:405-411. 